\title{
The effect of date of cut and barley substitution on gain and on the efficiency of utilization of grass silage by growing cattle
}

\section{Nutrient supply and energy partition}

\author{
BY D. E. BEEVER, S. B. CAMMELL, C. THOMAS, M. C. SPOONER, \\ M. J. HAINES AND D. L. GALE \\ AFRC Institute for Grassland and Animal Production, Animal and Grassland Research \\ Institute, Hurley, Maidenhead, Berkshire SL6 5LR
}

(Received 21 December 1987 - Accepted 25 April 1988)

1. The effect of harvesting date of perennial ryegrass (Lolium perenne) on the nutritive value of the resultant silage and the effect of substitution of late-cut silage with barley was examined in growing cattle. The diets comprised early-cut $(\mathrm{H})$ and late-cut $(\mathrm{L})$ silage offered alone or with $280(\mathrm{LCl})$ or 560 (LC2) $\mathrm{g}$ rolled barley/ $\mathrm{kg}$ total dry matter (DM) substituted for late-cut silage.

2. Both silages were prepared with the addition of formic acid $(850 \mathrm{~g} / 1 ; 2.4$ litres/t fresh weight) to a partially wilted crop, and were judged to be well fermented $(\mathrm{pH} \mathrm{3.9,3.8)} \mathrm{with} \mathrm{lactic} \mathrm{acid} \mathrm{contents} \mathrm{of} 108$ and $73 \mathrm{~g} / \mathrm{kg} \mathrm{DM}$, total nitrogen contents of 24.6 and $18.4 \mathrm{~g} / \mathrm{kg} \mathrm{DM}$ and ammonia- $\mathrm{N}$ contents of 121 and $124 \mathrm{~g} / \mathrm{kg}$ total $\mathrm{N}$ (values for early- and late-cut silages respectively).

3. Two experiments were conducted to measure duodenal non- $\mathrm{NH}_{3}-\mathrm{N}$ (NAN) supply in relation to $\mathrm{N}$ intake on the four diets (feeding level $18 \mathrm{~g} \mathrm{DM} / \mathrm{kg}$ live weight (LW)) and to examine the partition of the metabolizable energy (ME) supply from the four diets using open-circuit indirect calorimetry (three feeding levels, 14, 17 and $20 \mathrm{~g} \mathrm{DM} / \mathrm{kg} \mathrm{LW}$ ). The experiments were undertaken with eight and nine Friesian male castrates respectively with a mean starting weight of $300 \mathrm{~kg}$ and age 12 months. The animals used in Expt 1 had been previously fitted with cannulas into the dorsal rumen and the proximal duodenum.

4. NAN supply was significantly higher on diet $H$ than all other diets which were similar irrespective of the level of barley inclusion. Mean ME contents $(\mathrm{MJ} / \mathrm{kg} \mathrm{DM})$ of the two silages differed markedly (H 11.9, L 9.7) and barley addition (LCI and LC2) restored values to $10 \cdot 7$ and $11 \cdot 1 \mathrm{MJ} / \mathrm{kg} \mathrm{DM}$ respectively. Estimated NAN absorption in relation to energy supply was significantly higher for diet $\mathrm{H}(1.47 \mathrm{~g} / \mathrm{MJ} \mathrm{ME})$ than for all other diets (mean $1.25 \mathrm{~g} / \mathrm{MJ} \mathrm{ME}$ ).

5. Partition of ME supply using conventional linear analysis indicated dietary differences with respect to estimated $\mathrm{ME}$ for maintenance $(\mathrm{L}>\mathrm{H}, \mathrm{LCl}$ and $\mathrm{LC} 2)$ and efficiency of utilization of ME supplied above maintenance ( $\mathrm{L}>\mathrm{H}, \mathrm{LCl}$ and LC2), but difficulties in biological interpretation of these findings led to the use of exponential curve analysis. This provided an improved description of the findings, and whilst dietary differences were apparent, none were statistically significant. It was concluded that a single exponential equation could be used satisfactorily to describe all values.

6. The consequence of these findings in relation to the carcass retentions of energy, fat and protein reported by Thomas et al. (1988) is discussed and possible reasons for the discrepancies in energy retention measured by comparative slaughter balance and open-circuit indirect calorimetry are considered.

In the previous paper (Thomas et al. 1988) the consequence of delaying the harvesting of grass for ensiling on the nutritive value of the resultant silage when offered to beef cattle was examined, and the response to barley substitution of the later-cut material was quantified. That study was concerned with the examination of body and carcass retentions of energy, protein and fat at one feeding level (18 $\mathrm{g}$ dry matter (DM) $/ \mathrm{kg}$ live weight (LW)) using the comparative slaughter technique.

The objective of the present experiment, conducted in parallel with that reported by Thomas et al. (1988), was to examine the effect of increasing digestible nutrient intake either through an increase in silage digestibility or through an increase in the proportion of rolled barley given with the low digestibility silage on the supply of protein and metabolizable energy (ME), and the partition and efficiency of utilization of the ingested energy, using conventional digestion and open-circuit calorimetric procedures. The overall 
objectives were to provide information which may explain any production responses noted by Thomas et al. (1988) and to compare direct (comparative slaughter) and indirect (calorimetry) techniques for the assessment of energy retention. A preliminary report of this study has been published (Beever et al. 1984).

\section{MATERIALS AND METHODS}

Diets

The diets were as described by Thomas et al. (1988), and comprised grass silages made from a pure sward of perennial ryegrass (Lolium perenne cv. Melle) harvested on 27 May (early) or 23-27 June (late). Both silages were prepared from partially wilted grass with the addition of formic acid (ADD-F; BP Nutrition International plc; $850 \mathrm{~g}$ formic acid $/ 1 ; 2.4$ litres/ $t$ fresh weight) and were stored in bunker silos for 5 months before use.

The four diets offered to the animals comprised early-cut silage $(\mathrm{H})$ and late-cut silage alone (L) or substituted with $280(\mathrm{LC} 1)$ or $560(\mathrm{LC} 2) \mathrm{g}$ rolled barley DM/ $\mathrm{kg}$ total DM.

\section{Experimental design}

Expt 1 was designed to measure the flow of non-ammonia-nitrogen (NAN) into the small intestine in relation to $\mathrm{N}$ intake for the four diets and comprised two $4 \times 4$ Latin-Square designs with a total of eight animals. One level of feeding (18 g DM/ $\mathrm{kg} \mathrm{LW})$ was used. Expt 2 was designed to examine the effect of date of harvest and barley substitution on the ME content of the diets, the efficiency of utilization of $\mathrm{ME}$ for growth and fattening, and energy retention using open-circuit indirect calorimetry (Cammell et al. 1981, 1986). Each diet was offered at three levels. $(14,17$ and $20 \mathrm{~g} \mathrm{DM} / \mathrm{kg} \mathrm{LW})$ to nine steers in four periods $(n 36$, i.e. three observations for each diet at each feeding level). Between periods the animals were rerandomized to diets and feeding levels, such that during the experiment each animal was offered each diet once only, and received each feeding level at least once. Additionally two animals were retained throughout the experiment for the determination of fasting heat production.

\section{Animals and their management}

From an initial group of sixty-five British Friesian steers, forty-two and twenty respectively were selected at random for the comparative slaughter balance (Thomas et al. 1988), and the present study. From this total, eight animals were selected for Expt 1, and were fitted with PVC cannulas into the dorsal sac of the reticulorumen and the proximal duodenum using previously described techniques (Beever et al. 1978), approximately 2 months before the experiment commenced. A further eleven were selected for Expt 2 of which two were subsequently identified for the fasting heat production measurements. The remaining animal was removed from the experiment.

Until commencement of the experiment, all animals were given a medium quality grass hay (ad lib.) and barley (restricted), sufficient to sustain a daily $\mathrm{LW}$ gain of $0.6 \mathrm{~kg}$. At the start of the experiment, the animals were 12 months old and weighed approximately $300 \mathrm{~kg}$.

The diets were introduced over $14 \mathrm{~d}$ and each measurement period within each experiment lasted for approximately 21-28 d after diet change-over. Between periods, all diet change-overs were effected within $7 \mathrm{~d}$. The two animals destined for estimation of fasting heat production were given a mixture $(85: 15, \mathrm{w} / \mathrm{w}, \mathrm{DM}$ basis) of early-cut silage and rolled barley $(18 \mathrm{~g} \mathrm{DM} / \mathrm{kg} \mathrm{LW})$ until $7 \mathrm{~d}$ before the intended period of fast, when feeding level was reduced to $14 \mathrm{~g} \mathrm{DM} / \mathrm{kg} \mathrm{LW}$ before fasting. After completion of the measurements, re-alimentation was as described by Cammell et al. (1986). 
The eight animals for Expt 1 were held in 'resting pens' at all times, and the portable infusion and sampling apparatus developed by Evans et al. $(1981 a, b)$ was used as required. The animals for Expt 2 were housed in 'resting pens' between measurements, and moved, in sequence, to metabolism cages for estimates of faecal and urine output $(8 \mathrm{~d})$. Subsequently, they were transferred to similar metabolism cages within the respiration chambers and after $1 \mathrm{~d}$ for acclimatization, two $24 \mathrm{~h}$ measurements of gaseous exchange were conducted. The cattle were then returned to the 'resting pens' and diet change-overs commenced. Similar procedures were adopted for the fasting animals (excluding measurements of faecal and urine output). No measurements were made on any animal in either experiment until 2 weeks following completion of diet change-over.

All animals were kept in a partially controlled environment with continuous lighting. Fresh water and mineral blocks were freely available, and all animals were fed at 09.00 hours and 16.30 hours each day, when equal amounts of the daily feed allocation were given. Feed refusals, if any, were removed daily at 08.30 hours, weighed and toluene DM determinations were carried out subsequently to estimate actual DM intakes.

\section{Experimental procedure}

Expt 1. Intrarumen infusions of ruthenium phenanthroline (RuP) and CrEDTA were commenced $6 \mathrm{~d}$ before the collection of duodenal contents. Infusates were adjusted to provide $12 \mathrm{mg}$ ruthenium and $120 \mathrm{mg}$ chromium $/ \mathrm{kg} \mathrm{DM}$ offered, contained in a total volume of $500 \mathrm{ml} / \mathrm{d}$, and were infused continuously into the reticulorumen $(20 \mathrm{ml} / \mathrm{h})$ using portable infusion pumps (Evans et al. 1981 a). Subsequently, duodenal digesta collections were undertaken for two $24 \mathrm{~h}$ periods using portable samplers (Evans et al. $1981 \mathrm{~b}$ ), according to the procedures described by Beever et al. (1985).

Expt 2. Total faecal and urine outputs were collected concurrently for 8 and $5 \mathrm{~d}$ respectively, according to the procedures outlined by Cammell (1977). The animals were subsequently placed in open-circuit calorimeters and the procedures adopted to estimate heat production over two separate $24 \mathrm{~h}$ periods were identical to those described by Cammell et al. (1986). Measurements of gaseous exchange only were made with the fasted animals.

\section{Preparation and analysis of samples}

Samples of the offered feeds, taken at the time of experimental measurements, were frozen and subsequently freeze-dried (silage only) or oven-dried (barley), and ground (as appropriate) through a small laboratory mill. All duodenal-digesta samples were prepared according to Beever et al. (1985), to provide samples of whole and centrifuged digesta as outlined by Faichney (1975). These samples were subsequently freeze-dried and ground through a small laboratory mill before analysis.

Individual daily faecal samples for each animal were bulked on a fresh weight basis (Cammell et al. 1986) and portions were oven-dried to determine total faecal DM production. Further portions were freeze-dried and ground through a laboratory mill. The daily urine samples were accumulated on a fresh weight basis and subsamples were held frozen for subsequent analysis. A further subsample was dried under reduced pressure (Cammell et al. 1986) for determination of urine energy content.

Subsequently, all samples of feed, faeces, urine, duodenal digesta and intrarumen infusates were analysed, as appropriate, for DM (toluene distillation for silages), organic matter (OM), total $\mathrm{N}$, ammonia- $\mathrm{N}$, neutral- and acid-detergent fibre (NDF and ADF respectively), gross energy (GE), and $\mathrm{Ru}$ and $\mathrm{Cr}$ contents, as described by Thomas et al. (1988), Beever et al. (1978, 1985), Cammell et al. (1986) and Siddons et al. (1979). 


\section{Calculation of results}

Expt 1. Estimates of nutrient flow to the small intestine were obtained using the dual-phasemarker method proposed by Faichney (1975) and related to the quantities of individual nutrients consumed.

Expt 2. Estimates of dietary ME contents and ME intakes (MEI) were derived from estimates of GE intake (GEI), faecal and urine energy output and methane production, using the estimates of $\mathrm{CH}_{4}$ production derived from the calorimetry experiments appropriately corrected for small differences in DM consumption to those intakes recorded during the corresponding period of faecal and urine collection. Heat production was calculated according to Brouwer (1965) from the observed values for oxygen and carbon dioxide exchange and $\mathrm{CH}_{4}$ production (all corrected to DM intakes recorded during the balance measurements) and urinary $\mathrm{N}$ excretion (as measured). Energy-retention (ER) values were derived as the difference between MEI and heat production.

Two methods of analysis were used to examine the relation between ER and MEI, i.e. linear regression and exponential curve analysis, using both unscaled results and results scaled with respect to metabolic body-weight $\left(\mathrm{kg} \mathrm{LW}^{0.75}\right)$. The exponential curve analysis was described by Cammell et al. (1986) and used fasting heat production measurements which were obtained from two steers on three separate occasions during the experiment $(n 6)$. These values were included as data points in the analysis, but the curves were not constrained to pass through these data. The equation describing ER in relation to MEI as presented by Cammell et al. (1986) was:

$$
\mathrm{ER}=P_{3}\left[1-\exp \left(-P_{1}\left(\mathrm{MEI}-P_{2}\right)\right)\right]
$$

where $P_{1}$ is the curvature or specific rate of change, $P_{2}$ is the maintenance $\mathrm{ME}, P_{3}$ is the asymptote and $P_{3}\left[1-\exp \left(P_{1} P_{2}\right)\right]$ is the estimation of fasting heat production.

\section{Statistical analysis}

Values from Expt 1 were subjected to analysis of variance of a $4 \times 4$ Latin-Square design with two animals per sequence. There were four missing values for which estimated values were substituted leaving 14 residual df.

Due to the unbalanced design, values from Expt 2 were analysed using regression analysis by fitting animal, period and diet level effects. A total of six values were not obtained, due mainly to equipment malfunction, in particular aspects associated with data acquisition and retrieval. One of the observations not obtained on diet $L$ was due to the animal's continued inappetance. These six missing values were omitted from the analysis leaving 7 residual df. ER values were analysed using both linear regression and exponential curve fitting.

\section{RESULTS}

Chemical composition of the diets

The composition of the two silages and barley are given by Thomas et al. (1988). The silages had similar concentrations of DM, GE and ammonia- $\mathrm{N}$ (expressed as $\mathrm{g} / \mathrm{kg}$ total $\mathrm{N}$ ) and similar $\mathrm{pH}$ values whilst total $\mathrm{N}$ and total fermentation acids (particularly lactic acid) contents were higher, and fibre and ethanol concentrations lower for the early-cut silage than for the late-cut silage. The barley had a total $\mathrm{N}$ content intermediate between those of the two silages, and had a lower fibre content.

\section{Nutrient supply}

Values for duodenal flow of NAN, the estimated supply of absorbed NAN/MJ ME and the rumen digestion of NDF are presented in Table 1. 
Table 1. Mean quantities of total nitrogen (or non-ammonia- $N(N A N)$ ) and neutraldetergent fibre $(N D F)$ consumed and entering the small intestine of cattle consuming the four grass-silage-based diets, and the estimated supply of NAN per MJ metabolizable energy $(M E)$ consumed

\begin{tabular}{|c|c|c|c|c|c|}
\hline \multirow[b]{2}{*}{ Diet ... } & \multirow{2}{*}{$\begin{array}{c}\text { Early-cut } \\
\text { silage } \\
\text { H }\end{array}$} & \multicolumn{3}{|c|}{ Late-cut silage } & \multirow{2}{*}{$\begin{array}{c}\text { SE of } \\
\text { means }\end{array}$} \\
\hline & & $\mathrm{L}$ & $\mathrm{LCl}$ & LC2 & \\
\hline Total $N$ intake $(g / d)$ & $131 \cdot 0$ & $92 \cdot 8$ & 102.9 & $106 \cdot 8$ & $1 \cdot 72$ \\
\hline NAN flow $(\mathrm{g} / \mathrm{d})$ & 145.4 & $104 \cdot 2$ & $106 \cdot 3$ & 118.6 & 3.79 \\
\hline $\begin{array}{l}\text { Absorbed NAN* } \\
(\mathrm{g} / \mathrm{MJ} \mathrm{ME})\end{array}$ & 1.47 & $1 \cdot 33$ & $1 \cdot 17$ & $1 \cdot 23$ & 0.068 \\
\hline \multicolumn{6}{|l|}{$\mathrm{NDF}(\mathrm{kg} / \mathrm{d})$ : } \\
\hline Consumed & $2 \cdot 46$ & 3.18 & $2 \cdot 64$ & 1.85 & 0.049 \\
\hline Entering small intestine & 0.77 & 1.44 & $1 \cdot 42$ & $1 \cdot 08$ & 0.064 \\
\hline $\begin{array}{l}\text { NDF digestion in rumen } \\
(\mathrm{g} / \mathrm{kg} \text { intake })\end{array}$ & 687 & 547 & 462 & 416 & $28 \cdot 3$ \\
\hline
\end{tabular}

$\mathrm{H}$, early-cut silage alone; $\mathrm{L}$, late-cut silage alone; LCl, late-cut silage with $280 \mathrm{~g}$ barley dry matter (DM) $/ \mathrm{kg}$ total DM; LC2, late-cut silage with $560 \mathrm{~g}$ barley DM/kg total DM.

* Assuming small intestinal availability of NAN of $0 \cdot 63$.

$\mathrm{N}$ intakes on the three diets based on late-cut silage ranged from 93 to $107 \mathrm{~g} / \mathrm{d}$, and a similar range in duodenal NAN flows was obtained, with no evident effect due to barley inclusion. $\mathrm{N}$ intake for diet $\mathrm{H}$ was approximately 0.30 higher than for the other diets, and this was reflected in an elevated supply of duodenal NAN compared with the other three diets. The average effect of cereal inclusion with the late-cut silage diet was to reduce absorbed NAN supply/MJ ME compared with diet L (1.21 v. 1.33 g/MJ), whilst early cutting of grass gave a value of $1.47 \mathrm{~g} / \mathrm{MJ}$, if an average small intestinal availability of NAN of 0.63 was assumed for all diets.

NDF intakes were reduced by increased cereal inclusion in the late-cut silage diets, and this was accompanied by a marked reduction in the amount (from 1.74 to $0.77 \mathrm{~kg} / \mathrm{d}$ ) and proportion (from 547 to $416 \mathrm{~g} / \mathrm{kg}$ ) of fibre digested in the rumen. In contrast, for diet $\mathrm{H}$, the proportion of ingested NDF digested in the rumen was $687 \mathrm{~g} / \mathrm{kg}$, which was significantly $(P<0.01)$ higher than for all other diets.

\section{Energy metabolism}

Values relating to the mean quantities of GE consumed, and lost in the faeces, urine, and $\mathrm{CH}_{4}$ produced by cattle consuming the four diets at three levels of feeding are given in Table 2. Mean GEI ranged from 96 to $105 \mathrm{MJ} / \mathrm{d}$, and as expected, digestible energy (DE) content per MJ GEI was significantly $(P<0.05)$ higher with diet $\mathrm{H}(0.742 \mathrm{MJ})$ than with diet L (0.609) MJ). The values for the two cereal-containing diets were intermediate $(0.675$ and $0.695 \mathrm{MJ}$, not significantly $(P>0.05)$ different from each other, but significantly $(P<0.05)$ different from the two silage-only diets. Urine energy was significantly $(P<$ $0.05)$ higher for diet $\mathrm{H}(0.064 \mathrm{MJ} / \mathrm{MJ} \mathrm{DE}$ intake (DEI)) than for diets $\mathrm{L}, \mathrm{LC} 1$ and LC2 (mean $0.044 \mathrm{MJ} / \mathrm{MJ} \mathrm{DEI}$ ); the inclusion of barley appeared to have no effect on urine energy loss. $\mathrm{CH}_{4}$ energy per MJ GEI was lowest for diet $\mathrm{L}(0.067 \mathrm{MJ})$ and increased with barley inclusion to 0.074 (diet LC1) and 0.083 (diet LC2), but only with diet LC2 was the difference statistically significant $(P<0.05)$. The value for diet $\mathrm{H}(0.073 \mathrm{MJ})$ was similar to diet $\mathrm{LCl}$ and not significantly different from the other diets. In relation to DEI, $\mathrm{CH}_{4}$ energy values ranged from 0.098 to $0.118 \mathrm{MJ} / \mathrm{MJ}$, with diet $\mathrm{H}$ being significantly $(P<0.05)$ lower than diet LC2. 
Table 2. The mean quantities $(M J / d)$ of gross energy consumed and energy lost in the faeces, uri:g and methane produced by animals offered the four grass-silage-based diets

(Values for the three levels of feeding have been combined*)

\begin{tabular}{|c|c|c|c|c|c|}
\hline \multirow{3}{*}{$\begin{array}{l}\text { Diet ... } \\
\text { No. of replicates ... }\end{array}$} & \multirow{3}{*}{$\begin{array}{c}\text { Early-cut } \\
\text { silage } \\
\mathrm{H} \\
9\end{array}$} & \multicolumn{3}{|c|}{ Late-cut silage } & \multirow{3}{*}{$\begin{array}{l}\text { SE of } \\
\text { means }\end{array}$} \\
\hline & & $\mathbf{L}$ & $\mathrm{LCl}$ & $\mathrm{LC} 2$ & \\
\hline & & 7 & 8 & 6 & \\
\hline \multicolumn{6}{|l|}{ Gross energy $(\mathrm{MJ} / \mathrm{d})$ : } \\
\hline In feed & $104 \cdot 7$ & $96 \cdot 4$ & $100 \cdot 0$ & $101 \cdot 0$ & $2 \cdot 82$ \\
\hline In faeces & $27 \cdot 0$ & $37 \cdot 7$ & $32 \cdot 5$ & $30 \cdot 8$ & $1 \cdot 36$ \\
\hline In urine & 4.95 & $2 \cdot 79$ & $2 \cdot 83$ & 3.00 & 0.709 \\
\hline As methane & $7 \cdot 60$ & $6 \cdot 44$ & $7 \cdot 38$ & $8 \cdot 28$ & 0.485 \\
\hline $\begin{array}{l}\text { Apparent digestibility } \\
\text { of gross energy }\end{array}$ & $0 \cdot 742$ & 0.609 & 0.675 & 0.695 & 0.0127 \\
\hline \multicolumn{6}{|l|}{$\begin{array}{l}\text { Partition of digestible } \\
\text { energy }(\mathrm{MJ} / \mathrm{MJ})\end{array}$} \\
\hline Urine & 0.064 & 0.048 & $0 \cdot 042$ & 0.043 & 0.0093 \\
\hline Methane & 0.098 & $0 \cdot 110$ & 0.109 & 0.118 & 0.0060 \\
\hline Metabolizable energy & 0.838 & $0 \cdot 842$ & 0.848 & 0.839 & 0.0134 \\
\hline
\end{tabular}

H, early-cut silage alone; L, late-cut silage alone; LC1, late-cut silage with $280 \mathrm{~g}$ barley dry matter (DM)/kg total DM; LC2, late-cut silage with $560 \mathrm{~g}$ barley DM/kg total DM.

* For details, see p. 310 .

Table 3. The mean metabolic body-weights $\left(\mathrm{kg}\right.$ live weight $\left.t^{0.75}\right)$ and the intakes of metabolizable energy and the estimates of energy retention when the four grass-silagebased diets were offered at three feeding levels* to growing cattle

\begin{tabular}{|c|c|c|c|c|c|c|}
\hline \multirow[b]{2}{*}{ Diet... } & \multirow{2}{*}{$\begin{array}{l}\text { Feeding } \\
\text { level }\end{array}$} & \multirow{2}{*}{$\begin{array}{c}\text { Early-cut } \\
\text { silage } \\
\mathrm{H}\end{array}$} & \multicolumn{3}{|c|}{ Late-cut silage } & \multirow{2}{*}{$\begin{array}{l}\mathrm{SE} \text { of } \\
\text { means }\end{array}$} \\
\hline & & & $\mathrm{L}$ & $\mathrm{LC} 1$ & LC2 & \\
\hline $\begin{array}{l}\text { Metabolic body-wt } \\
\left(\mathrm{kg} \text { live } \mathrm{wt}^{0.75}\right)\end{array}$ & $\begin{array}{l}1 \\
2 \\
3\end{array}$ & $\begin{array}{l}75 \cdot 54 \\
74 \cdot 50 \\
74 \cdot 17\end{array}$ & $\begin{array}{l}75 \cdot 48 \\
76 \cdot 27 \\
78 \cdot 00\end{array}$ & $\begin{array}{l}75 \cdot 54 \\
77 \cdot 64 \\
77 \cdot 74\end{array}$ & $\left.\begin{array}{l}76 \cdot 61 \\
76 \cdot 39 \\
75 \cdot 33\end{array}\right\}$ & 0.693 \\
\hline $\begin{array}{l}\text { Metabolizable } \\
\text { energy intake } \\
(\mathrm{MJ} / \mathrm{d})\end{array}$ & $\begin{array}{l}1 \\
2 \\
3\end{array}$ & $\begin{array}{l}55 \cdot 0 \\
60 \cdot 0 \\
78 \cdot 5\end{array}$ & $\begin{array}{l}41 \cdot 3 \\
52 \cdot 4 \\
54 \cdot 6\end{array}$ & $\begin{array}{l}48 \cdot 4 \\
53 \cdot 4 \\
68 \cdot 7\end{array}$ & $\left.\begin{array}{l}50 \cdot 0 \\
59 \cdot 4 \\
66 \cdot 7\end{array}\right\}$ & $2 \cdot 11$ \\
\hline $\begin{array}{l}\text { Energy retention } \\
(\mathrm{MJ} / \mathrm{d})\end{array}$ & $\begin{array}{l}1 \\
2 \\
3\end{array}$ & $\begin{array}{r}8 \cdot 8 \\
12 \cdot 2 \\
18 \cdot 4\end{array}$ & $\begin{array}{r}-1 \cdot 4 \\
7 \cdot 9 \\
7 \cdot 3\end{array}$ & $\begin{array}{r}6.9 \\
7.9 \\
16.7\end{array}$ & $\left.\begin{array}{r}7 \cdot 7 \\
11 \cdot 2 \\
15 \cdot 8\end{array}\right\}$ & $2 \cdot 32$ \\
\hline
\end{tabular}

$\mathrm{H}$, early-cut silage alone; L, late-cut silage alone; LCl, late-cut silage with $280 \mathrm{~g}$ barley dry matter (DM) $/ \mathrm{kg}$ total DM; LC2, late-cut silage with $560 \mathrm{~g}$ barley DM/kg total DM.

* For details, see p. 310 . 
Table 4. Equations relating energy retention to metabolizable energy $(M E)$ intake $(M E I)$ for cattle consuming the four grass-silage-based diets, and predictions of energy retention based on the curvilinear model

\begin{tabular}{|c|c|c|c|c|c|}
\hline \multirow[b]{2}{*}{ Diet ... } & & \multirow{2}{*}{$\begin{array}{c}\text { Early-cut } \\
\text { silage } \\
\mathrm{H}\end{array}$} & \multicolumn{3}{|c|}{ Late-cut silage } \\
\hline & & & $\mathbf{L}$ & LCl & LC2 \\
\hline \multicolumn{6}{|l|}{ Linear regression: unscaled } \\
\hline Slope $\left(k_{t}\right)$ & & 0.416 & 0.588 & 0.401 & $0 \cdot 361$ \\
\hline Constant & & -13.38 & $-24 \cdot 30$ & $-12 \cdot 28$ & $-9 \cdot 87$ \\
\hline \multicolumn{6}{|l|}{ Estimated maintenance } \\
\hline $\mathrm{ME}(\mathrm{MJ} / \mathrm{d})$ & & $32 \cdot 2$ & $41 \cdot 3$ & $30 \cdot 7$ & $27 \cdot 4$ \\
\hline$r$ & & 0.901 & 0.778 & 0.967 & 0.967 \\
\hline RSD & & $2 \cdot 555$ & $2 \cdot 493$ & $1 \cdot 713$ & $1 \cdot 206$ \\
\hline \multicolumn{6}{|l|}{$\begin{array}{l}\text { Linear regression: scaled } \\
\text { to metabolic body-wt }\end{array}$} \\
\hline Slope $\left(k_{\mathrm{p}}\right)$ & & 0.433 & 0.739 & 0.498 & 0.433 \\
\hline Constant & & $-0 \cdot 193$ & $-0 \cdot 412$ & $-0 \cdot 233$ & -0.189 \\
\hline Estimated maintenance $\mathrm{ME}$ & & & & & \\
\hline$\left(\mathrm{kJ} / \mathrm{kg} \mathrm{LW}^{0.75}\right.$ per d) & & $445 \cdot 1$ & $561 \cdot 0$ & $468 \cdot 4$ & $455 \cdot 5$ \\
\hline$r$ & & $0 \cdot 895$ & 0.799 & 0.980 & 0.963 \\
\hline RSD & & 0.0349 & 0.0303 & 0.0153 & 0.0157 \\
\hline \multicolumn{6}{|l|}{ Curvilinear model: unscaled } \\
\hline$P_{1}(\mathrm{MJ} / \mathrm{MJ})$ & Mean & 0.0140 & 0.0067 & 0.0169 & $0 \cdot 0219$ \\
\hline & $\mathrm{SE}$ & 0.00506 & 0.00285 & 0.00347 & 0.00240 \\
\hline$P_{2}(\mathrm{MJ} / \mathrm{d})$ & $\begin{array}{l}\text { Mean } \\
\text { SE }\end{array}$ & $\begin{array}{l}37 \cdot 3 \\
2 \cdot 87\end{array}$ & $\begin{array}{c}41 \cdot 6 \\
0 \cdot 70\end{array}$ & $\begin{array}{c}35.4 \\
1.65\end{array}$ & $\begin{array}{l}33 \cdot 5 \\
0 \cdot 00240\end{array}$ \\
\hline$P_{3}(\mathrm{MJ} / \mathrm{d})$ & $\begin{array}{l}\text { Mean } \\
\text { SE }\end{array}$ & $\begin{array}{l}43 \cdot 6 \\
15 \cdot 60\end{array}$ & $\begin{array}{l}93 \cdot 8 \\
44 \cdot 37\end{array}$ & $\begin{array}{l}36 \cdot 6 \\
7.67\end{array}$ & $\begin{array}{l}27 \cdot 8 \\
3 \cdot 05\end{array}$ \\
\hline$F_{2}(\mathrm{MJ} / \mathrm{d})$ & $\begin{array}{l}\text { Mean } \\
\text { SE }\end{array}$ & $\begin{array}{l}29 \cdot 8 \\
6 \cdot 25\end{array}$ & $\begin{array}{c}30 \cdot 0 \\
6.93\end{array}$ & $\begin{array}{c}30 \cdot 0 \\
3.67\end{array}$ & $\begin{array}{c}30 \cdot 0 \\
1 \cdot 82\end{array}$ \\
\hline $\begin{array}{l}\text { Predicted energy retention } \\
(\mathrm{MJ} / \mathrm{d}) \text { at } \mathrm{MEI}(\mathrm{MJ} / \mathrm{d}) \text { of : }\end{array}$ & & $\cdot$ & & & \\
\hline 30 & & -4.7 & -7.5 & -3.5 & $-2 \cdot 2$ \\
\hline 40 & & +1.6 & -1.0 & $+2 \cdot 7$ & $+3 \cdot 7$ \\
\hline 50 & & $+7 \cdot 1$ & $+5 \cdot 1$ & $+8 \cdot 0$ & $+8 \cdot 4$ \\
\hline 60 & & +11.9 & ND & $+12 \cdot 4$ & $+12 \cdot 2$ \\
\hline 70 & & +16.0 & ND & ND & ND \\
\hline
\end{tabular}

$\mathrm{H}$, early-cut silage alone; $\mathrm{L}$, late-cut silage alone; $\mathrm{LCl}$, late-cut silage with $280 \mathrm{~g}$ barley dry matter (DM) $/ \mathrm{kg}$ total DM; LC2, late-cut silage with $560 \mathrm{~g}$ barley DM/kg total DM; ND, values not determined as MEI outside range of those fed in the experiment; RSD, residual standard deviation; $P_{1}$, curvature; $P_{2}$, maintenance; $P_{3}$, asymptote; $F_{2}$, fasting heat production; $k_{t}$, predicted efficiency of utilization of $\mathrm{ME} ; \mathrm{LW}$, live weight.

Dietary ME contents ranged from $9.73 \mathrm{MJ} / \mathrm{kg} \mathrm{DM}$ (diet L) to 10.66 and $11.07 \mathrm{MJ} / \mathrm{kg}$ DM (diets $\mathrm{LCl}$ and LC2) in response to barley inclusion, compared with a value of $11.93 \mathrm{MJ} / \mathrm{kg} \mathrm{DM}$ for diet $\mathrm{H}$. For all diets, $\mathrm{ME}$ averaged 0.842 of $\mathrm{DE}$, whilst metabolizability (ME: GE) of the diets increased from 0.52 (L) to 0.58 and 0.59 (diets $\mathrm{LC1}$ and LC2) compared with $0.62(\operatorname{diet} \mathrm{H})$.

In Table 3, metabolic body-weight, MEI and estimated ER for all diets at each feeding level are presented. Linear regressions (both unscaled and scaled to metabolic body-weight) and exponential curve analysis (unscaled only) of ER $v$. MEI are presented in Table 4.

With diets LC1, LC2 and H, the range in daily MEI (level 1-level 3) varied between 17 
and $24 \mathrm{MJ}$. Unfortunately, due to some feed refusals, the range was lower on diet $\mathrm{L}$ (13 $\mathrm{MJ}$ ), reflecting the difficulty in achieving consistent intakes in excess of $17-18 \mathrm{~g} \mathrm{DM} / \mathrm{kg}$ LW on this diet. Across all diets, daily MEI ranged from 41 to $79 \mathrm{MJ} / \mathrm{d}$ with ER of -1.4 to $+18 \cdot 4 \mathrm{MJ} / \mathrm{d}$.

Using unscaled values, predicted values for efficiency of utilization of $\operatorname{ME}\left(k_{\mathrm{f}}\right)$ for the two cereal-containing diets and diet $\mathrm{H}$ were not significantly different $(P>0.05$; mean 0.39$)$ but were markedly lower than the value for diet $L$. Estimated $M E$ requirements for maintenance $\left(P_{2}\right)$ were 27.4 to $32.2 \mathrm{MJ} / \mathrm{d}$ for diets LC1, LC2 and $\mathrm{H}$, compared with $41.3 \mathrm{MJ} / \mathrm{d}$ for diet $\mathrm{L}$. Scaling the values to metabolic body-weight did not markedly change the situation. $\mathrm{k}_{\mathrm{f}}$ for diets $\mathrm{H}, \mathrm{LCl}$ and $\mathrm{LC} 2$ increased by 2-9 percentage units with a mean $P_{2}$ requirement of $456 \mathrm{~kJ} / \mathrm{kg} \mathrm{LW}{ }^{0.75}$ per $\mathrm{d}$. These values contrasted with unrealistically high values of $k_{\mathrm{f}}(0.74)$ and $P_{2}$ cost $\left(561 \mathrm{~kJ} / \mathrm{kg} \mathrm{LW}^{0.75}\right.$ per d) for diet $\mathrm{L}$.

With exponential curve analysis, $P_{2}$ estimates ranged from 33.5 to $41.6 \mathrm{MJ} / \mathrm{d}$, suggesting higher values for the two forage diets $(39.5 \mathrm{MJ} / \mathrm{d})$ than for the cereal-containing diets $(34.5 \mathrm{MJ} / \mathrm{d}$ ). All predicted fasting heat production values (mean $30.0 \mathrm{MJ} / \mathrm{d}$ ) were close to the measured values (mean $29.9 \mathrm{MJ} / \mathrm{d}$ ). As MEI increased on all diets the relations suggested that positive ER would occur first on diet LC2, followed by diets $\mathrm{LC1}, \mathrm{H}$ and $\mathrm{L}$, in that order. However, the rate of decline in ER with increasing MEI was estimated to be greatest on diet LC2 (0.022 MJ/MJ) followed by diets LC1 and $\mathrm{H}$ (mean $0.016 \mathrm{MJ} / \mathrm{MJ}$ ), and all markedly higher than the value obtained on diet $\mathrm{L}(0.007 \mathrm{MJ} / \mathrm{MJ})$. Using these equations to predict ER at variable MEI within the range of MEI observed in the experiment, it can be seen that at MEI between 40 and $50 \mathrm{MJ} / \mathrm{d}$ ER tended to be higher on the two cereal-containing diets whilst at intakes of $60 \mathrm{MJ} \mathrm{ME} / \mathrm{d}$, all diets (except diet L) gave predicted ER of approximately $12 \mathrm{MJ} / \mathrm{d}$. With diet $\mathrm{L}$, on the basis of the intakes achieved in the present experiment, it would appear that ER in excess of $5 \mathrm{MJ} / \mathrm{d}$ (predicted) to $7 \mathrm{MJ} / \mathrm{d}$ (observed) are unlikely to be achieved in practice.

Exponential curve analysis of the values scaled to metabolic body-weight did not significantly alter the relations, and this analysis is not presented.

Further examination of the unscaled values for energy partition was undertaken by (1) combining the values according to feed type (i.e. silage only and cereal-containing diets) and (2) by combining all values using both the linear and exponential models. From an examination of the resultant analysis it was established that, as compared with an analysis of all values, separate equations for the two feed types did not account for a significantly greater proportion of the variation. Consequently, one overall relation, based on exponential curve analysis is presented as the most appropriate one to describe the values. The terms derived from this analysis are:

$$
P_{1} 0.0140 \text { (SE 0.00267), } \quad P_{2} 37.57 \text { (SE 1.132), } \quad P_{3} 43.25 \text { (SE 8.049), } \quad F_{2} 29.93 \text { (SE 3.316), }
$$

indicating a mean $P_{2}$ requirement of $37.6 \mathrm{MJ} / \mathrm{d}$ and a predicted fasting heat production $\left(F_{2}\right)$ of $29.93 \mathrm{MJ} / \mathrm{d}$, giving an 'overall' $K_{m}$ between fasting and maintenance of 0.796 .

\section{Discussion}

Previous studies which have examined the digestion of non-additive or formic-acid-treated grass silages (Beever et al. 1971, 1977; Møller \& Thomson, 1977; Kelly et al. 1978; Siddons et al. 1979; Beever, 1980) have consistently demonstrated reduced duodenal NAN fiows with respect to $\mathrm{N}$ intake, whilst Thomson \& Beever (1980) showed small-intestinal uptake of amino acid- $\mathrm{N}$ from wilted and direct-cut silage to be only 0.31 and 0.41 respectively of $\mathrm{N}$ intake. In contrast, duodenal NAN supplies in the present study were $1 \cdot 12$ and $1 \cdot 11$ of total $\mathrm{N}$ intake for the late- and early-cut silages. The late-cut silage had a low $\mathrm{N}$ content 
$(19 \cdot 6 / \mathrm{kg} \mathrm{OM})$ and, on the basis of relations which have been established between duodenal NAN flow (in relation to $\mathrm{N}$ intake) and $\mathrm{N}$ content in the dietary OM (Hogan \& Weston, 1970; Beever et al. $1986 a$; Ulyatt et al. 1988), albeit predominantly for fresh forages, a net gain in duodenal NAN flow in relation to $\mathrm{N}$ intake could be expected. Conversely, the early-cut silage contained $26.7 \mathrm{~g} \mathrm{~N} / \mathrm{kg} \mathrm{OM}$, which would suggest a reduced duodenal NAN flow compared with $\mathrm{N}$ intake. The results obtained did not, however, support this suggestion and the elevated duodenal NAN supply was unexpected. Recently, Beever $e t$ al. $(1986 b)$ reported similar rumen gains of $\mathrm{N}$ when formic-acid-treated grass silage was given with a low-protein concentrate to dairy cows.

Barley substitution of the late-cut silage had only a marginal effect on duodenal NAN supply, such that all diets based on late-cut silage gave an estimated NAN absorption of between 1.17 and $1.33 \mathrm{~g} / \mathrm{MJ}$ ME compared with $1.47 \mathrm{~g} / \mathrm{MJ}$ ME for the early-cut silage. The possibility of an increased passage of starch to the small intestine of cattle on the barley diets was not examined, but the consequence of increased cereal consumption on fibre digestion in the rumen was detected. Although NDF consumption was highest on diet L, the amount degraded in the rumen was identical $(1.72 \mathrm{~kg} / \mathrm{d})$ for the two silage-only diets, and hence the proportion of ingested NDF digested in the rumen was lower on diet $\mathrm{L}$. The extent and proportional digestion of ingested NDF declined further, as the level of cereal substitution was increased, in line with the changes in NDF digestibility reported by Thomas et al. (1988).

The production experiment reported by Thomas et al. (1988) clearly identified dietary differences with respect to ER, and from a comparison of diets $\mathrm{H}$ and LC2 it was concluded that in order to achieve similar levels of ER on both diets, it would be necessary to increase ME supply on early-cut silage by approximately $9 \%$.

ER determined by calorimetry were found on all diets at the highest level of feeding to be higher than those estimated by comparative slaughter, with the positive effect of cereal inclusion being most evident. This was apparent even when differences in intake between the two experiments were taken into account. Contrary to the findings obtained from the slaughter experiment, the ER derived by calorimetry for diet $\mathrm{H}$ exceeded those obtained for diet LC2. However, linear regression analysis of the values for the individual diets failed to establish significant differences between diets $\mathrm{H}, \mathrm{LC} 1$ and LC2 with respect to $k_{\mathrm{f}}$ and estimates of $P_{2}$ costs. In contrast, a major problem with respect to diet $\mathrm{L}$ was identified. Both the patterns of feed intake and measurement of heat production were quite erratic on this diet, especially when the highest level of feeding was being offered. Thus the range in MEI in the experiment was reduced and this, combined with increased variations in daily heat production (and hence ER), led to linear analysis of the values for diet $\mathrm{L}$ giving relatively imprecise relations and biologically irreconcilable results. Use of exponential curve analysis was unlikely to improve this situation for diet $\mathrm{L}$, and when the values for the two forages were combined, the effects of the late-cut silage values were still evident. Thus whilst the ER values presented in Table 3 indicated the inferiority of diet $\mathrm{L}$, it was not statistically possible to describe the values other than by a single exponential curve for all diets.

This problem of low ER with low-quality diets of low intake potential has been encountered in other studies (Thomson et al. 1979). With hindsight it may have been advisable to extend the period of measurement for gaseous exchange with animals receiving the late-cut silage. In the present experiment only $2 \mathrm{~d}$ of measurement were made, but it would have been feasible to increase this to at least $4 \mathrm{~d}$, which should have provided an improved data-base relating feed intake to heat production. Second, it may have been advisable to increase the number of observations on this diet.

Using the overall exponential relation derived for all diets it was possible to predict ER 
Table 5. Comparison of energy retentions $(M J / d)$ estimated by comparative slaughter $(C S T)$, predicted from the overall exponential relation derived from the calorimetric studies (CAL) and predicted from Agricultural Research Council (1980) using separate $(A R C-S)$ or an overall $(A R C-O)$ relation

\begin{tabular}{|c|c|c|c|c|c|c|c|}
\hline \multirow[b]{2}{*}{ Diets ... } & \multirow{2}{*}{$\begin{array}{c}\text { Early-cut } \\
\text { silage } \\
\text { H }\end{array}$} & \multicolumn{3}{|c|}{ Late-cut silage } & \multirow{2}{*}{$\begin{array}{l}\text { MSPE } \\
\left(\mathrm{MJ}^{2}\right)\end{array}$} & \multirow{2}{*}{$\begin{array}{r}\text { Bias } \\
(\mathrm{MJ})\end{array}$} & \multirow{2}{*}{$\begin{array}{l}\mathrm{SE} \text { of } \\
\text { means }\end{array}$} \\
\hline & & $\mathrm{L}$ & $\mathrm{LCl}$ & $\mathrm{LC} 2$ & & & \\
\hline $\mathrm{CST}$ & $12 \cdot 24$ & 5.48 & $9 \cdot 23$ & 14.58 & - & - & - \\
\hline CAL & 17.07 & $11 \cdot 15$ & 13.88 & $15 \cdot 16$ & $22 \cdot 62$ & 4.04 & 1.80 \\
\hline ARC-S & 18.04 & $9 \cdot 50$ & 13.27 & 15.65 & $19 \cdot 97$ & 3.73 & 1.77 \\
\hline ARC-O & $18 \cdot 41$ & 8.66 & 14.55 & 16.83 & $23 \cdot 48$ & $4 \cdot 23$ & 1.70 \\
\hline
\end{tabular}

$\mathrm{H}$, early-cut silage alone; L, late-cut silage alone; LCl, late-cut silage with $280 \mathrm{~g}$ barley dry matter (DM) $/ \mathrm{kg}$ total DM; LC2, late-cut silage with $560 \mathrm{~g}$ barley DM $/ \mathrm{kg}$ total DM; MSPE, mean square prediction error (for details, see Bibby \& Tentenburg (1977) and Theil (1966)).

$$
\begin{array}{lll}
\text { ARC-S: } & \text { Forage diets } & k_{\mathrm{f}}=1.32 q_{\mathrm{m}}-0.318, \\
& \text { Mixed diets } & k_{\mathrm{f}}=0.38 q_{\mathrm{m}}+0.282, \\
\text { ARC-O: } & \text { All diets } & k_{\mathrm{f}}=0.78 q_{\mathrm{m}}+0.006
\end{array}
$$

where $k_{\mathrm{f}}$ is the predicted efficiency of utilization of metabolizable energy for growth and fattening and $q_{\mathrm{m}}$ is the measured metabolizability of the gross energy of the diet.

in the animals used in the comparative slaughter balance (Thomas et al. 1988) using actual DM intakes recorded in that experiment and the ME concentrations derived in the present study. The values are presented in Table 5 along with predicted ER using relations proposed by the Agricultural Research Council (1980) for all diets (ARC-O) or for forage and mixed diets separately (ARC-S).

For all diets, except $\mathrm{L}$, there was a reasonably close agreement between the predicted ER, values based on calorimetry and those predicted by the calorimetrically-based Agricultural Research Council (1980) system (ARC-S, ARC-O), whilst the calorimetry-derived value for diet $\mathrm{L}$ was approximately $2 \mathrm{MJ} / \mathrm{d}$ higher than that predicted on the basis of ARC-O and ARC-S. However, only with diet LC2 was there an acceptable agreement between the prediction of ER derived by calorimetry and that estimated by comparative slaughter. With the other diets it was clear that there was a considerable over-prediction amounting to between 3 and $6 \mathrm{MJ} / \mathrm{d}$, equivalent to an increased daily LW gain of $0.25 \mathrm{~kg}$ based on the energy value of gain determined by Thomas et al. (1988). This apparent discrepancy between ER estimates based on comparative slaughter and calorimetry in the present study using similar diets fed to virtually identical cattle, has been illustrated by others (Bull et al. 1976) but it remains difficult to establish the major causes of the effect. Failure in the present study to establish specific dietary relations between energy intake and ER and the consequential use of a combined relation may have contributed to this discrepancy. It is interesting to note from the comparison presented in Table 5 that the largest discrepancies were detected on diets L and LC1 which were the diets which promoted the lowest energy gains. Environmental conditions prevailing at the time of experimentation may in part have contributed to the effect. The animals used in the comparative slaughter balance were maintained at ambient temperature (approximately $-3^{\circ}$ to $+6^{\circ}$ ) compared with the higher temperatures $\left(14^{\circ}\right)$ to which the animals used for calorimetry were subjected. Additionally, activity costs would have been greater with the animals in the comparative slaughter study. 
However, even together, these aspects seem unlikely to account for a major part of the differences observed in ER. An additional consideration is that the heat production measurements were obtained indirectly from measurement of gaseous exchanges and it may be that the equation proposed by Brouwer (1965) to calculate heat production from gaseous exchange is not applicable to all dietary circumstances. With respect to acclimatization of the animals before measurements of gaseous exchange, the trend towards a reduced heat production was opposite to that which would be expected if the animals responded adversely to their new environment, and consequently problems in acclimatization can be ruled out as a source of error.

In a recent review of methodological problems associated with ER studies, Graham (1982) referred to the general overprediction of ER and hence underprediction of energy requirement which occurs with the Agricultural Research Council (1980) system, which was derived from calorimetric values, is compared with the National Research Council (1970) system which is based on slaughter balance, and cited the studies of Graham \& Searle (1972) where, for the same diets offered to sheep, $k_{\mathrm{f}}$ estimates based on calorimetry were $0.50-0.60$ compared with values of $0.30-0.40$ derived from slaughter experiments. In attempting to resolve this discrepancy, Graham (1982) suggested that there is an appreciable energy expenditure associated with the physiological state of immature animals and that this state responds rather slowly to changes in feed intake. Thus Graham (1982) concluded that in short-term calorimetry studies, where animals are changed from one diet to another, there is generally insufficient time for the animals to adapt fully to their new nutritional state and such experimental procedures may limit the general applicability of the values obtained by calorimetry. This issue is also discussed by Turner $\&$ Tayler (1983) and is now being investigated experimentally in this laboratory, in order that some of the discrepancies between comparative slaughter and calorimetry may be resolved.

It would, however, be premature to suggest that all the errors lie within the calorimetric estimates of ER. In this respect Thomas et al. (1988) high-lighted possible inaccuracies as a result of errors in the estimation of fat content of gain arising from a relatively poor relation between weight of fat and empty-body-weight in the initial slaughter group, and the method of fat analysis used. If the average error of underestimation of 8-9\% in fat content derived by Woodward et al. (1976) using the Foss-let method, as used by Thomas et al. (1988), is applied to the values in Table 5, then ER estimated by comparative slaughter would increase and the change would account for between 7 and $20 \%$ of the difference between calorimetric and comparative slaughter estimates. Nevertheless a considerable between-method difference would continue to exist and reconciliation of such remains a research priority.

When the intakes of ME and the levels of absorbed NAN were computed for the animals used in the production study (Thomas et al. 1988) and related to empty-body retentions of energy, protein and fat (see Table 6), some interesting differences in the utilization of ME and absorbed NAN were observed. Thus whilst total ME, absorbed NAN and absorbed NAN/MJ ME were all higher for diet $\mathbf{H}$ than for diet LC2, the highest empty-body retentions of energy, protein and fat were recorded on the high-cereal diet. Even when the values were expressed in relation to $\mathrm{ME}$ available for production, using the $P_{2}$ requirements given in Table 4, the performance differences still existed. On the basis of current systems designed to meet the energy and protein requirements of growing ruminants (Agricultural Research council, 1980, 1984), it would not be possible to predict such variations in animal response. This indicates a weakness in the present systems in that the factors governing the partition of absorbed nutrients are not sufficiently well represented. It must be concluded that explanation for such responses lies at a more fundamental biochemical level than 
Table 6. The effect of stage of harvest and barley supplementation on energy and protein supply and the retention of energy, protein and fat in growing cattle

\begin{tabular}{|c|c|c|c|c|}
\hline \multirow[b]{2}{*}{ Diet... } & \multirow{2}{*}{$\begin{array}{c}\text { Early-cut } \\
\text { silage } \\
\text { H }\end{array}$} & \multicolumn{3}{|c|}{ Late-cut silage } \\
\hline & & $\mathrm{L}$ & $\mathrm{LCl}$ & LC2 \\
\hline ME intake $\left(M J / L W^{0.75}\right.$ per d) & 0.93 & 0.76 & 0.83 & 0.87 \\
\hline NAN supply (g/LW $/$ W $^{07}$ per d) & $2 \cdot 14$ & 1.60 & 1.54 & 1.72 \\
\hline Absorbed NAN/ME supply (g/MJ) & 1.47 & 1.33 & $1 \cdot 17$ & 1.23 \\
\hline \multicolumn{5}{|l|}{ Empty body } \\
\hline Energy retention $(\mathrm{MJ} / \mathrm{d})$ & $12 \cdot 2$ & $5 \cdot 5$ & $9 \cdot 2$ & 14.6 \\
\hline Protein $(\mathrm{g} / \mathrm{d})$ & 87 & 31 & 76 & 116 \\
\hline Fat $(\mathrm{g} / \mathrm{d})$ & 260 & 121 & 189 & 302 \\
\hline
\end{tabular}

$\mathrm{H}$, early-cut silage alone; $\mathrm{L}$ late-cut silage alone; $\mathrm{LCl}$, late-cut silage with $280 \mathrm{~g}$ barley dry matter (DM) $/ \mathrm{kg}$ total DM; LC2, late-cut silage with $560 \mathrm{~g}$ barley DM/kg total DM; ME, metabolizable energy; NAN, non-ammonianitrogen; LW, live weight.

simply the provision of ME and absorbed protein, and that the importance of the nature of $\mathrm{ME}$ with respect to individual nutrients must be recognized. It is pertinent to note that Thomas et al. (1988) demonstrated that the proportion of the ME derived from digestible cell walls varied markedly with diet type and concluded that the level of animal performance achieved appeared to be inversely related to the contribution from cell-wall materials. Clearly, this suggests that a fuller description of the nature of the ME will be required if animal responses are to be predicted accurately from a knowledge of the diet consumed. Only once the precise causes of the animal responses noted in the present and other similar studies are fully understood will the full impact of the effect of harvesting date of grass, and the strategic use of supplements, on ruminant livestock systems be realizable in practice.

The authors wish to acknowledge the technical assistance provided by Messrs A. R. Austin, R. J. Barnes, R. B. Marshall, M. A. Dhanoa and R. Pilgrim. The Animal and Grassland Research Institute is an Agricultural and Food Research Council Institute and the studies reported were wholly commissioned by the Ministry of Agriculture, Food and Fisheries.

\section{REFERENCES}

Agricultural Research Council (1980). The Nutrient Requirements of Farm Livestock no. 2, Ruminants. Farnham Royal: Commonwealth Agricultural Bureaux.

Agricultural Research Council (1984). The Nutrient Requirements of Farm Livestock no. 2, Ruminants, Suppl. no. 1. Farnham Royal: Commonwealth Agricultural Bureaux.

Beever, D. E. (1980). In Forage Conservation in the 80's, Proceedings of European Grassland Federation Meeting, Brighton. British Grassland Society Occasional Publication no. 11, pp. 131-143 [C. Thomas, editor]. Hurley, Maidenhead, British Grassland Society.

Beever, D. E., Cammell, S. B., Haines, M. J., Gale, D. L. \& Thomas, C. (1984). Animal Production $37,533$.

Beever, D. E., Dhanoa, M. S., Losada, H. R., Evans, R. T., Cammell, S. B. \& France, J. (1986a). British Journal of Nutrition 56, $439-454$.

Beever, D. E., Kellaway, R. C., Thomas, D. J., MacRae, J. C., Evans, C. C. \& Wallace, A. S. (1978). Journal of Agricultural Science, Cambridge 90, 157-163.

Beever, D. E., Thomson, D. J., Cammell, S. B. \& Harrison, D. G. (1977). Journal of Agricultural Science, Cambridge 88, 61-70.

Beever, D. E., Thomson, D. J., Pfeffer, E. \& Armstrong, D. G. (1971). British Journal of Nutrition 26, $123-134$. Beever, D. E., Thomson, D. J., Siddons, R. C. \& Thomas, C. (1986 b). Journal of Dairy Science 69, 219. 
Beever, D. E., Thomson, D. J., Ulyatt, M. J., Cammell, S. B., Austin, A. R. \& Spooner, M. C. (1985). British Journal of Nutrition 54, 763-775.

Bibby, J. \& Tentenburg, H. (1977). Prediction and Improved Estimation in Linear Models. London: John Wiley \& Sons.

Brouwer, E. (1965). In Energy Metabolism, European Association for Animal Production Publication no. 11, pp. 441-443. [K. L. Blaxter, editor]. London and New York: Academic Press.

Bull, L. S., Tyrrell, H. F. \& Reid, J. T. (1976). Energy Metabolism of Farm Animals, European Association of Animal Production Publication no. 19, p. 137-140.

Cammell, S. B. (1977). Technical Report no. 24. Hurley, Maidenhead: Grassland Research Institute.

Cammell, S. B., Beever, D. E., Skelton, K. V. \& Spooner, M. C. (1981). Laboratory Practice 30, $115-119$.

Cammell, S. B., Thomson, D. J., Beever, D. E., Haines, M. J., Dhanoa, M. S. \& Spooner, M. C. (1986). British Journal of Nutrition 55, 669-680.

Evans, R. T., Hayes, D. G. \& Beever, D. E. (1981 a). Laboratory Practice 30, 591-593.

Evans, R. T., Skelton, K. V. \& Beever, D. E. (1981 b). Laboratory Practice 30, 997-1000.

Faichney, G. J. (1975). In Digestion and Metabolism in the Ruminant, pp. 277-291 [I. W. McDonald and A. C. I. Warner, editors]. Armidale, Australia: University of New England Publishing Unit.

Graham, N. McC. (1982). Energy Metabolism of Farm Animals, European Association of Animal Production Publication no. 29, pp. 108-111.

Graham, N. McC. \& Searle, T. W. (1972). Australian Journal of Agricultural Research 23, 97.

Hogan, J. P. \& Weston, R. H. (1970). In Physiology of Digestion and Metabolism in the Ruminant, pp. 474-485 [A. T. Phillipson, editor]. Newcastle upon Tyne: Oriel Press.

Kelly, N. C., Thomas, P. C. \& Chamberlain, D. G. (1978). Proceedings of the Nutrition Society 37, 34A.

Møller, P. D. \& Thomson, K. V. (1977). Institut for Husdjurens Utfordring och vard, Rapport no. 54, pp. 27-54.

National Research Council (1970). Nutrient Requirements of Beef Cattle, 5th ed. Washington DC: National Academy of Sciences.

Siddons, R. C., Evans, R. T. \& Beever, D. E. (1979). British Journal of Nutrition 42, 535-545.

Theil, H. (1966). Applied Economic Forecasting, Chapter 2. Amsterdam: North Holland Publishing Company.

Thomas, C., Gibbs, B. G., Beever, D. E. \& Thurnham, B. R. (1988). British Journal of Nutrition 60, $297-306$.

Thomson, D. J. \& Beever, D. E. (1980). In Digestive Physiology and Metabolism in Ruminants, pp. 291-308. [Y. Ruckebusch and P. Thivend, editors.] Lancaster: MTP Press Ltd.

Thomson, D. J., Fenton, J. S. \& Cammell, S. B. (1979). British Journal of Nutrition 41, 223-229.

Turner, H. G. \& Tayler C. S. (1983). World Review of Nutrition and Dietetics 42, 135-190.

Ulyatt, M. J., Thomson, D. J., Beever, D. E., Evans, R. T. \& Haines, M. J. (1988). British Journal of Nutrition 60 , $137-149$.

Woodward, C. J. H., Trayhurn, P. \& James, W. P. T. (1976). British Journal of Nutrition 36, 567-570. 